\title{
THE ASSESSMENT OF SAFETY SYSTEMS IN WWER-1000 NUCLEAR REACTOR USING IAEA SIMULATOR
}

\author{
Tran Dang Khoa ${ }^{a^{*},}$ Trinh Thi Tu Anh ${ }^{b}$
}

\author{
${ }^{a}$ The Faculty of Nuclear Science, National Tsing Hua University, Taiwan, China \\ ${ }^{b}$ The Research Management and International Cooperation Department, Dalat University, \\ Lamdong, Vietnam \\ Article history \\ Received: November $18^{\text {th }}, 2016$ | Received in revised form: December $09^{\text {th }}, 2016$ \\ Accepted: December $12^{\text {th }}, 2016$
}

\begin{abstract}
In this study, the operation and response capability of safety system in nuclear reactor WWER-1000 was analyzed during the accidents that involved the failure of main circulation pump or feed water pumps. The nuclear reactor WWER-1000 simulator developed by IAEA showed that safety systems such as the EP, the PP and the AUU are capable of controlling the reactor power by adjusting the control rods during the accidents. Also, the ACP allowed the nuclear reactor to operate safely at 65\%, $61 \%$ and $39 \%$ power for the wheel jam of MCP-1, the trip of MCP-1 and the FWP-1 accident, respectively. Additionally, the water in steam generator remained at the original value $(224 \mathrm{~mm})$ by $S G$ water level controller to ensure the heat exchange within the reactor.
\end{abstract}

Keywords: Feed water pump; Main circulation pump; Safety system; WWER-1000 nuclear reactor.

\section{INTRODUCTION}

WWER is an abbreviation for Water Energy Reactor. It is a pressure vessel type nuclear reactor with water used both as moderator and coolant, resulting in a thermal neutron spectrum. The main distinguishing features of the WWER compared to other PWRs are horizontal steam generators and hexagonal fuel assemblies. The WWER-1000 (IAEA, 2011) core is composed of fuel assemblies (FA) having hexagonal formant located on a hexagonal grid with constant pitch of about $236 \mathrm{~mm}$. Additionally, the steam generator (SG) is intended for heat removal from primary circuit coolant and forming saturated steam in the secondary circuit. Steam generators at NPP with WWER-1000 reactors are of the horizontal type. The characteristics of SG are: Pressure in SG is

\footnotetext{
${ }^{*}$ Corresponding author: Email: mininbox12@gmail.com
} 
$(6.27 \pm 0.19) \mathrm{MPa}$ and Water level is $(320 \pm 50) \mathrm{mm}$ (IAEA, 2011, p.16). The number following the reactor type usually indicates power of the unit. Thus, WWER-1000 designates a unit with $1000 \mathrm{MW}$ electrical power.

The nuclear reactor WWER-1000 simulator developed by IAEA is a useful tool that allows nuclear engineers and students to have a broad and specific overview about the operation and component's parameters within the WWER-1000 nuclear reactor during normal operation or accidents. The IAEA simulator can be used in personal computer for educational purpose and for technical staffs training. Some safety systems are presented in this simulator. They are the emergency protection (EP) system, the preventive protection (PP) system, the reactor power reducing and limiting device (ROM), the automatic power control (ACP), the steam generators emergency feed water system and the accelerated unloading unit (AUU). These systems are used for reactor protection and control. They are capable of adjusting the reactivity via control rod systems which are suspended above the reactor core by electromagnetic forces. Each of those systems has different functions in the nuclear reactor (IAEA, 2011). Specifically, the functions of the above systems are described below:

- The emergency protection (EP) system: When an emergency protection signal occurs, all control rods drop down and the reactor power rapidly decrease to 0 .

- The automatic power control (ACP) maintains the reactor power at a certain value.

- When preventive protection-1 signal occurs, groups of control rods are moved down; A function of preventive protection is also carried out by ROM. When preventive protection-2 signal occurs, plant automation prohibits withdrawing control rods.

- The steam generators emergency feed water system maintains the water level in steam generators at original value. The steam generators emergency feed water system controls the water level in the SG by automatically adjusting its coefficient; Its high coefficient allows more water to be fed into the SG and 
vice-versa.

- $\quad$ The accelerated unloading unit (AUU) rapidly reduces the reactor power.

This work presents the nuclear reactor WWER-1000 safety systems and the accident sequences that involve the failure of main circulation pump or feed water pump. The focus of this work is to analyze the accident sequences and to assess the responses of safety system within those events.

\section{MATERIALS AND METHODS}

\subsection{Simulation utilization}

The WWER-1000 Reactor Simulator was originally developed for personnel training. It was executed on a personal computer in real time and provides a dynamic response with sufficient fidelity. After reducing the scope of modelling to the systems essential for overall correct response and fidelity and cutting out a number of auxiliary systems the Simulator became suitable for educational and information purposes. The interaction between the user and the simulator was organized through a set of display screens and a mouse.

\subsection{Accident sequences}

Accident sequences of the wheel jam of MCP-1, the trip of MCP-1 and the FWP1 are described in this section, respectively. To select the training task for execution, double-click on the item in the list of training tasks (Figure 1).

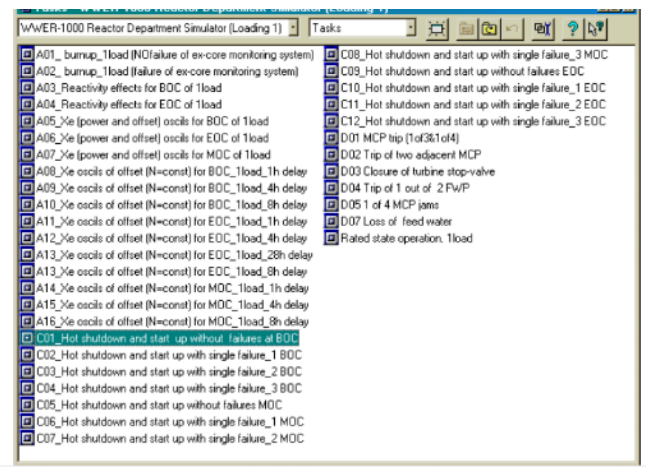

Figure 1. Task selection for execution 


\subsubsection{MCP-1 wheel jam}

From the training window in Figure 1, select the tasks D05 " 1 of 4 MCP jam" and then "start".

Table 1. MCP-1 wheel jam accident sequence

\begin{tabular}{ccl}
\hline Time $(\mathrm{s})$ & Reactor power $(\%)$ & Events \\
\hline 0 & 100.00 & Normal operation \\
30 & 99.98 & MCP-1 wheel jam \\
33 & 99.20 & The signal "dP MCP $<2.5$ " appears in TAB screen \\
60 & 91.30 & Change in the water level of SG-1 \\
300 & 65.00 & Safely operation of reactor at $65 \%$ power \\
\hline
\end{tabular}

From 0 to 29 second: The reactor is operated under normal condition. The SGs parameters are stable; At 30 second: MCP-1 wheel jams. The original water level in SG is $224.5 \mathrm{~mm}$. The original temperature of hot leg and cold leg SG-1 are $310.8^{\circ} \mathrm{C}$ and 286.1 ${ }^{0} \mathrm{C}$, respectively; At 33 second: The $\mathrm{CR}$ group 10 are inserted into reactor core. Others remain the same. The reactor power decreases to $99.2 \%$ power. The water level in SG-1 rapidly decreases to $198 \mathrm{~mm}$; At 60 second: The reactor power is about $91.3 \%$. The SG1 water level controller is activated to make the water level reaches the original value (224-226 mm). The temperature of hot leg and cold leg SG-1 are $278.1^{\circ} \mathrm{C}$ and $276.1^{\circ} \mathrm{C}$ respectively. The temperature difference of hot leg and cold leg is reduced to make the water level in SG-1 recover; and at 300 second: The reactor operates at $65 \%$ with the support from the control and protection system.

\subsubsection{MCP-1 trip}

From the training window (Figure 1), select the "Rated state operation". Close the MCP-1 manually in the Primary Circulation Circuit Page (1C) and then "start".

From 0-4 second: The reactor is operated under normal condition. Parameters of reactor core and primary circuit components remain stable; At 5 second: MCP-1 trips. The appearance of "MCP trip" signal in TAB screen leads to the activation of preventive protection (PP-1) system. At this time, the water level in SG-1 begins to reduce; At 10 second: When the PP is activated, the automatic power controller (ACP) is also activated 
to reduce the reactor power to $66 \%$. Also, the CR group 10 is inserted into the reactor core; At 35 second: the water level in SG-1 is $215 \mathrm{~mm}$. The water level controller of SG1 starts to make the water level of SG-1 return to original value $(224 \mathrm{~mm})$ to ensure the heat exchange within the nuclear reactor; At 85 second: Water level in SG-1 returns to original value and begins to exceed the original value. Therefore, the water level controller continues, inhibit water level from exceeding the original value; and at 115 second: The CR group 10 position is about $75 \%$ from the bottom. The ACP allows the reactor to be operated at $61 \%$ power.

Table 2. MCP-1 trip accident sequence

\begin{tabular}{ccl}
\hline Time (s) & Power $(\%)$ & Events \\
\hline 0 & 100.00 & Normal operation \\
5 & 99.99 & MCP-1 trip \\
6 & 99.99 & Signal "MCP trip" appear in TAB screen \\
10 & 97.48 & Automatic power control is activated \\
35 & 86.50 & Changes in SG-1 parameters \\
115 & 59.89 & CR group 10 is inserted into reactor core (about 75\%) \\
305 & & Reactor core parameter become stable \\
\hline
\end{tabular}

\subsubsection{FWP-1 trip}

From the training window (Figure 1), select the D04 "Trip of 1 out of 2 FWP" and then "start".

Table 3. FWP-1 trip accident sequence

\begin{tabular}{ccl}
\hline Time $(\mathrm{s})$ & Power $(\%)$ & Events \\
\hline 0 & 100.00 & Normal operation \\
10 & 99.99 & FWP-1 trip \\
11 & & Signal "TDFWP trip" arises \\
14 & 58.27 & CR bank 1 is inserted \\
45 & 46.89 & SGs water level decreases below $215 \mathrm{~mm}$ \\
70 & 39.00 & ACP is on \\
\hline
\end{tabular}

From 0-9 second: The reactor operates under normal condition. Parameters of reactor core and primary circuit components remain stable; At 10 second: The FWP-1 
trips. After that, the "TDFWP trip" arises in TAB screen results in accelerated unit unloading (AUU) actuation; At 14 second: the CR bank 1 dropped into the core. The signal "CR drop" arises leads to the actuation of preventive protection 2 to limit the power raise. Also, the power limiting controller (ROM) starts decreasing reactor power to the preset value 39\% power; At 45 second: The water level in four SGs is below $215 \mathrm{~mm}$. The SG level controller is activated; and at 70 second: The automatic power controller is on and CR bank 10 is adjusted to maintain the reactor power.

\section{RESULTS AND DISCUSSION}

The explanation for the accident sequence are mentioned in this section. One of the most crucial factors during any accidents is the water level in the SG, which ensure the heat exchange of the reactor, was also precisely discussed. Besides, the activities of some safety systems were also taken into consideration.

\subsection{MCP-1 jam}

The reactor power and the relationship between the SG water level and the SG water level controller coefficient are shown in the following figures.

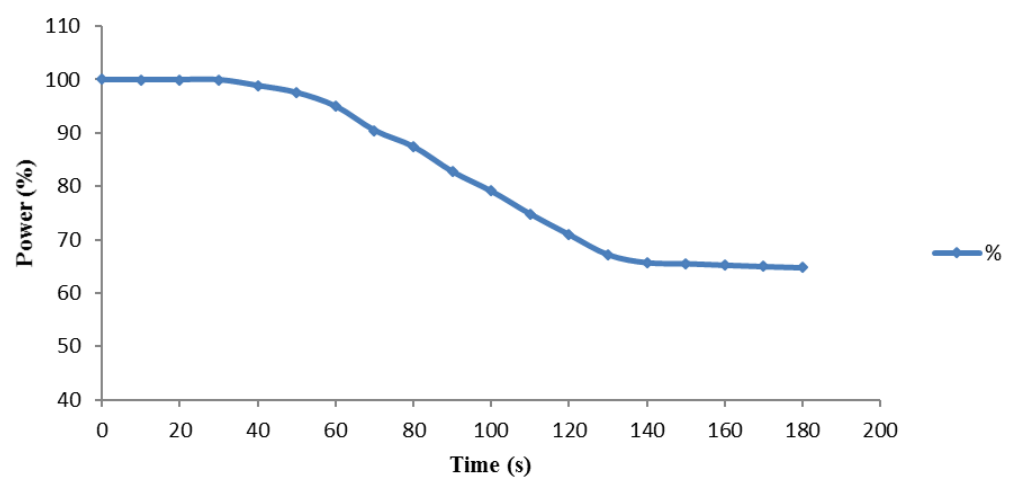

Figure 2. Nuclear reactor power during MCP-1 jam accident

In this case, the accident occurs at 30 second and it takes over 100 seconds to reduce to $65 \%$. After that, the ACP controls the power so that the reactor is able to safely operate. Figure 2 shows that the ACP is a useful tool to maintain the reactor power. 


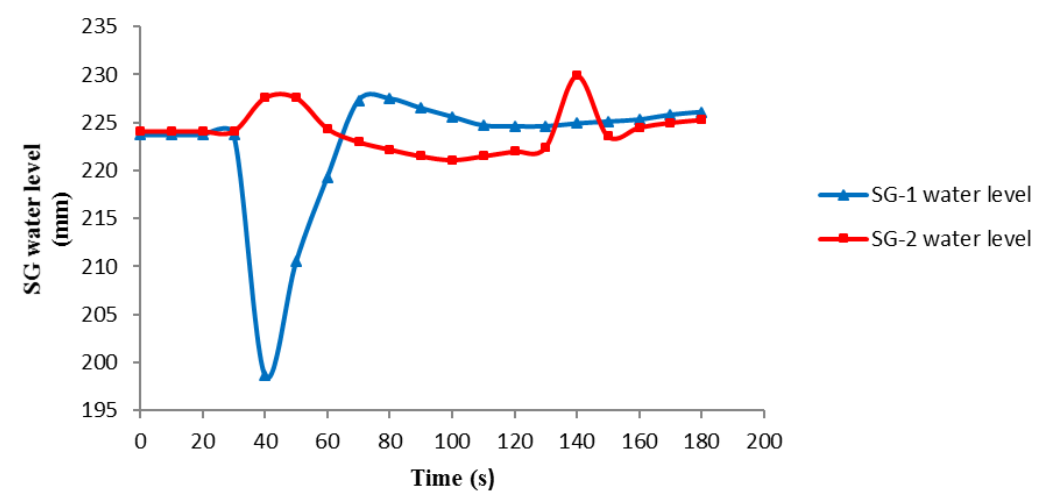

Figure 3. SG water level during MCP-1 jam

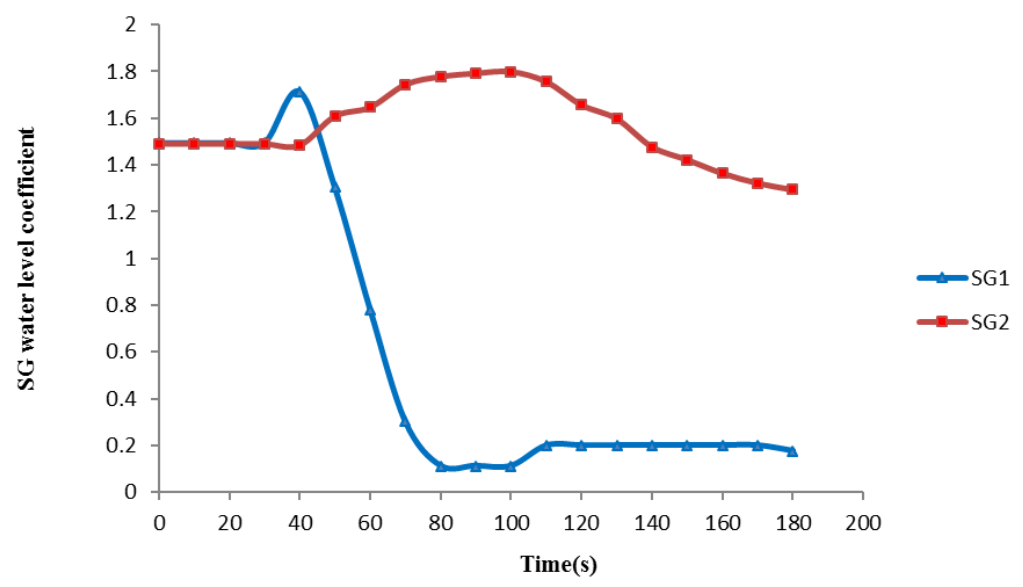

Figure 4. SG water level controller coefficient

Another important concern is how the water level in SG is maintained at original value $(224 \mathrm{~mm})$. The relationship between the SG water level and the SG water level controller coefficient are showed in Figure 3 and Figure 4. Specifically, the decrease of water level in SG-1 leads to the increase of SG-1 water level controller coefficient. Also, there are not significant changes in SG-2 water level so the SG-2 water level controller remains the same. The heat exchange within the nuclear reactor is ensured so that the nuclear reactor can safely operates regardless of reactor power.

The MCP jam is considered to be a serious accident in nuclear reactor. When the MCP-1 wheel jams, the water level in SG-1 rapidly decrease to $198 \mathrm{~mm}$ within 10 seconds since the accident occurs. Figure 5 shows that the water level in SG-1 decreases to 198 
$\mathrm{mm}$ in only 10 seconds after the accident happens. This short period may not be enough for external intervention in fixing the problem.

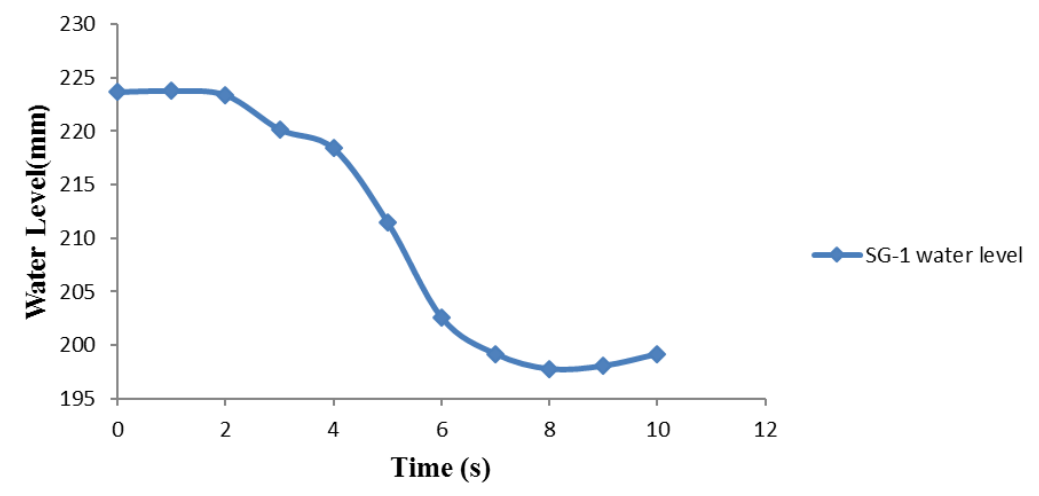

\section{Figure 5. SG-1 water level change due to the MCP-1 jam accident}

Without the EP system, the MCP-1 wheel jams reduce the coolant flow into the reactor and result in the increase of primary side temperature and the reactor power. However, when the pressure drops of the SG-1 is lower than $2.5 \mathrm{~atm}$, the EP makes SCRAM happen. The EP system inserts the control rod system to reduce the reactor power. However, the automatic power controller is activated to allow the nuclear reactor to operate safely at $65 \%$ power by inserting only the control rod bank 10 into the reactor. The position of control rod bank 10 at this time is $30 \%$ from the bottom. Without the $\mathrm{ACP}$, the power will rapidly decrease to 0 in 5 seconds.

Also, when the SG-1 water level is $198 \mathrm{~mm}$, it begins to recover at the original value $(224 \mathrm{~mm})$ thanks to the SG-1 water level controller and the decreases of loop-1 hot leg. At first, the SG-1 water level controller coefficient is about 1.4 (the water level is 224 $\mathrm{mm}$ ) and it increase to 1.7 when the water level is $198 \mathrm{~mm}$. Additionally, the decrease of temperature to $294^{\circ} \mathrm{C}$ in the loop- 1 hot leg is also a reason for the recovery of SG-1 water level.

\subsection{MCP-1 trip}

The reactor power and the relationship between the SG water level and the SG water level controller coefficient are shown in the following figures.

The MCP-1 trips virtually right after the reactor begins to operate. Similar to the 
MCP-1 wheel jams, it also takes about 90 seconds to be stable at $61 \%$. And the power is maintained by ACP.

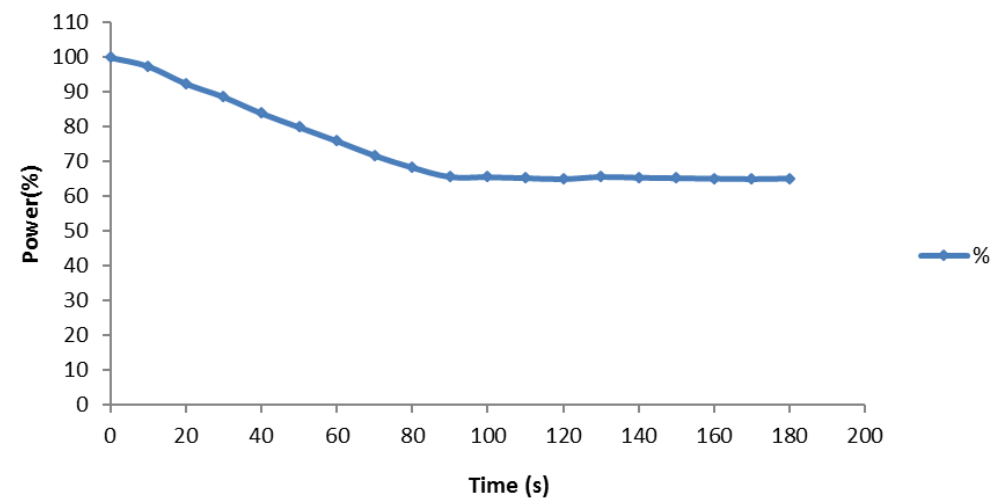

Figure 6. Nuclear reactor power during MCP-1 trip

The relationship between the SG water level and the SG water level controller coefficient is shown in two figures (Figure 7 and Figure 8). One of the important factors to ensure the heat exchange of the reactor core is the SG water level stability. And these two figures show how the water level in SGs is controlled during the accident MCP-1 trip sequence. Specifically, the decrease of water level in SG-1 leads to the increase of SG-1 water level controller coefficient. After being stable, the SG-1 water level controller begins to increase so that the water level in SG-1 is capable of reaching original value. Also, there is no significant change in SG-2 water level so the SG-2 water level controller remains the same. This helps to ensure the heat exchange within the nuclear reactor so that it can safely operate regardless of reactor power.

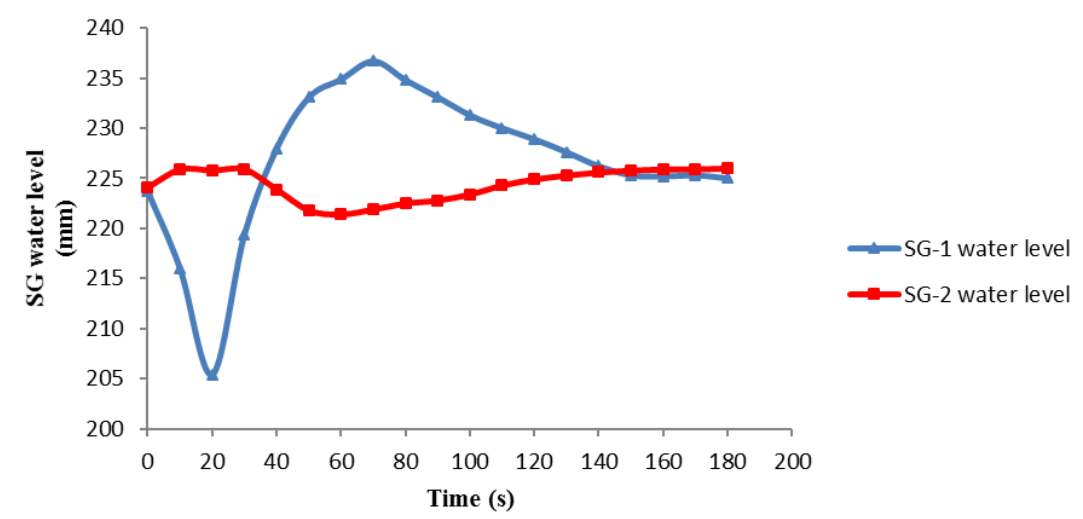

Figure 7. SG water level during MCP-1 trip 


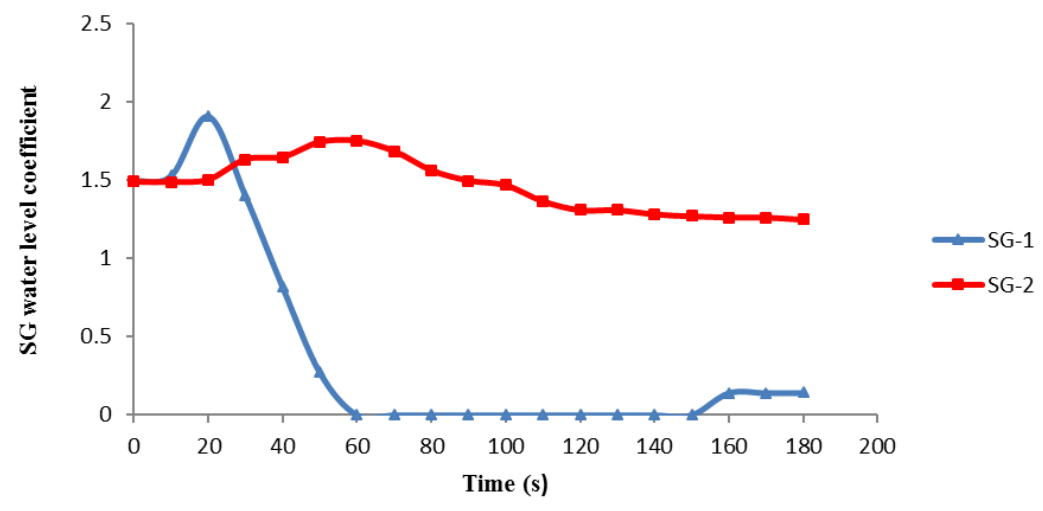

Figure 8. SG water level controller coefficient

The MCP trip occurs so the SG is not provided with sufficient amount of water for the heat exchange in reactor core. However, different from the MCP wheel jams, when MCP-1 trips due to the lack of power or any reason, it is still running thanks to the inertia force (Andrushenko et al., 2012) and this results in the gradual decrease of SG-1 water level. Figure 9 shows that after the accident, the water level in SG-1 gradually decreases to $198 \mathrm{~mm}$. It takes about 18 seconds to do that, longer than those in MCP-1 wheel jam (about 10 seconds).

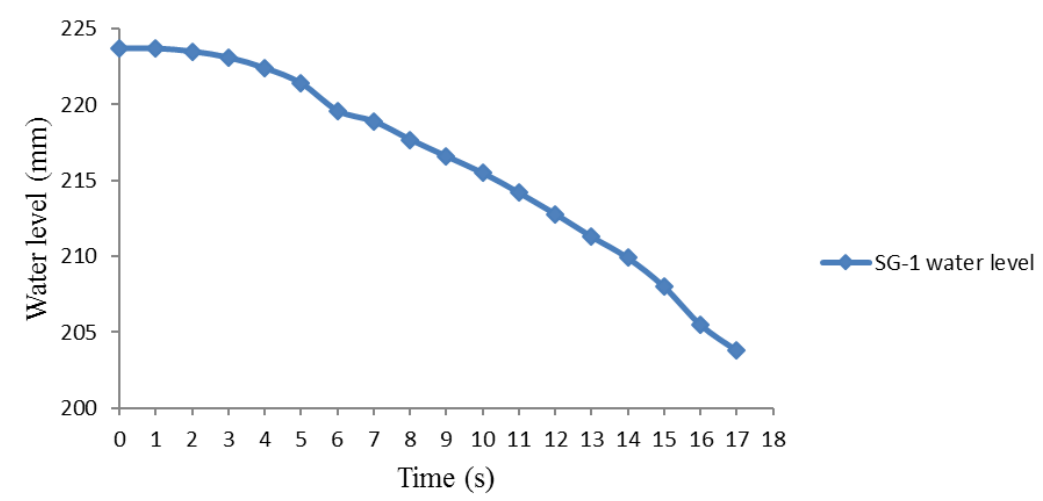

Figure 9. SG-1 water level change due to the MCP-1 trip accident

In this accident, the activation of PP-1 results from the signal "MCP trip" in TAB screen. While the EP system inserts all the control rod banks into reactor core, the PP-1 system just inserts some of the control rod banks into the reactor core, control rod bank 10 for instance. The position of the control rod bank 10 is about $25 \%$ from the bottom. At the same time, ROM reduces the power at $66 \%$ in 2 minutes.

In addition, the water level controller manages the water level to remain stable in 
SG. Specifically, when the water level is about $198 \mathrm{~cm}$, the coefficient of the water level controller increases approximately 1.7 and it makes the water level increase. When the water level is about $230 \mathrm{~mm}$, the coefficient of the water level controller starts to decreases (about 0.3 ) so that the water level in the SG return to original value. The hot leg temperature also decreases from 3200C (the accident happens) to 2900C (the water level in SG-1 recovers) and it is another reason for the recover in SG-1 water level. It takes only 10 seconds for the water level in SG-1 to recover to the original value (224 $\mathrm{mm})$.

\subsection{FWP-1 trip}

The reactor power and the SG water level are shown in the following graphs (Figure 10 and Figure 11).

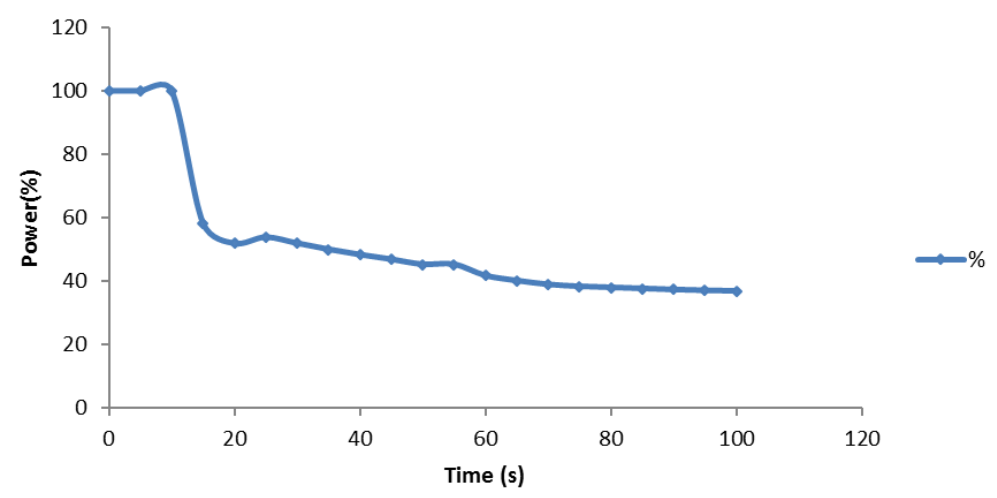

Figure 10. Nuclear reactor power during FWP-1 trip accident

The most significant difference between the MCP-1 wheel jam, MCP-1 trip accident and the FWP-1 trip is that the power rapidly decreases to about $50 \%$ in 10 seconds. After that, the ACP put the reactor safely operates at $39 \%$ power.

Also, the water levels are affected by the accident not only in one SG but also in all SGs. All SGs are not provided with sufficient amount of water due to the failure of FWP-1. Fortunately, the water level controller of all SGs are capable of increasing the water level in all SGs to the original value and continue to ensure the heat exchange in the reactor. 


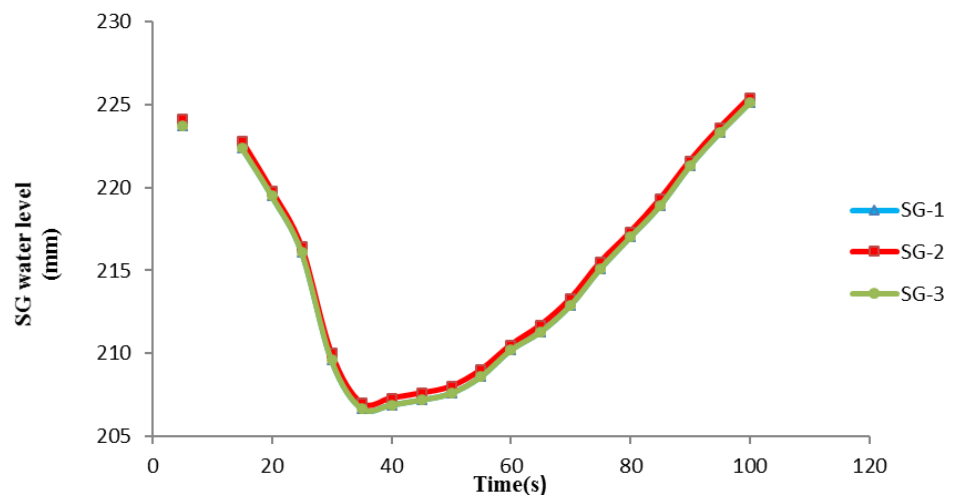

Figure 11. SG water level in FWP-1 trip

The "TDFWP trip" signal arises as soon as the FWP-1 trip. Also, the accelerated unit unloading is actuated. The AUU reduces the reactor power by inserting 2 control rod banks, bank 10 and bank 1 . The control rod bank 1 is totally inserted into the reactor and the position of control rod bank 10 is $50 \%$ from the bottom. This explains why the reactor power rapidly decreases to $45 \%$ within 10 seconds. The signal "CR drop" arises when CR bank 1 is inserted into the reactor core. It leads to the actuation of preventive protection-2 to avoid the raise of reactor power. The PP-2 still keeps the position of control rod bank 1 and bank 10 (0\% and $50 \%$ from the bottom, respectively).

Without those systems (the AUU and PP-2), the reactor power can-not be reduced and the temperature in the reactor core may exceed the acceptance limit and threaten the heat exchange within the reactor. Besides, the power limiting controller starts to decrease reactor to the preset value 39\% to ensure the safety of the reactor. All the SG water level controller coefficients begin to increase to supply water for SG when SG water level begins to decrease. After the power decreases to 39\%, automatic power control is ON and maintains the reactor power.

\section{CONCLUSION}

This work aims to assess the capability of safety systems during some accidents in nuclear reactor. During any accidents within the nuclear reactor, the safety systems are capable of working and responding well to ensure the safety of the nuclear reactor. Specifically, the safety system allows the reactor to operate safety at lower power $65 \%$, $61 \%$ and 39\% power for the wheel jam of MCP-1, the trip of MCP-1 and the FWP-1 
accident, respectively, with the support of ACP (automatic power control). The above powers are maintained during accidents until others system are ready to recover the power. This simulation also proves that the nuclear reactor can be safe during some accidents with the support of safety system so there will be enough time for the reactor operators to repair the accident causes to reduce the risk for the nuclear reactor.

\title{
REFERENCES
}

Andrushenko, X. A., Aphrov, A. M., Vaciliev, B. I., Genheralov, V. N., Koxounov, K. B., Shemchenkov, I. M., \& Ukraixev, V. P. (2012). Nhà máy điện hạt nhân sử dụng lò phản úng WWER-1000. Hà Nội, Việt Nam: NXB Khoa học và Kỹ thuật.

IAEA (2011). WWER-1000 Reactor manual ( $3^{\text {rd }}$ ed.). Retrieved from https:// www.iaea.org/NuclearPower/Downloads/Simulators/WWER-1000-SimulatorManual-2011.10.pdf.

\section{ĐÁNH GIÁ Hệ THỐNG AN TOÀN TRONG LÒ PHẢN ÚNG WWER-1000 BẰNG PHẦN MỀM MÔ PHỎNG IAEA}

\author{
Trần Đăng Khoa ${ }^{*}$, Trịnh Thị Tú Anh ${ }^{b}$
}

\author{
${ }^{a}$ Khoa Khoa học Hạt Nhân, Truoòng Đại học Thanh Hoa, Đài Loan, Trung Quốc \\ ${ }^{b}$ Phòng Quản lý Khoa học - Hợp tác Quốc tế, Truờng Đại học Đà Lạt, Lâm Đồng, Việt Nam \\ "Tác giả liên hệ: Email: minibox12@gmail.com \\ Lịch sử bài báo \\ Nhận ngày 18 tháng 11 năm 2016 | Chỉnh sửa ngày 09 tháng 12 năm 2016 \\ Chấp nhận đăng ngày 12 tháng 12 năm 2016
}

\section{Tóm tắt}

Bài báo này phân tích và đánh giá khả năng hoạt động và đáp ưng của hệ thống an toàn thu động trong lò phản ứng WWER-1000 khi xảy ra các sụ cố liên quan đến máy bơm. Qua phần mềm mô phỏng lò phản ứng WWER-1000 được phát triển bởi IAEA có thể thấy rằng các hệ thống an toàn nhu EP, PP và AUU điều khiển công suất lò phản ứng bằng cách điều chỉnh vị trí của các thanh điều khiển trong các tai nạn. Hệ thống ACP đưa lò phản ứng hoạt động an toàn ở các mức công suất lần lượt là $65 \%, 61 \%$ và $39 \%$ công suất ban đầu đối với sư cố máy bơm tuần hoàn số 1 bị kẹt, máy bơm tuần hoàn số 1 bị hỏng và máy bơm nuớc cấp số 1 bị hỏng. Bên cạnh đó, bộ điều khiến mưc nước của các bình sinh hơ giúp ổn định mức nước danh định $(224 \mathrm{~mm})$ để đảm bảo khả năng trao đổi nhiệt bên trong lò phản úng.

Từ khóa: Bơm cấp nước; Bơm tuần hoàn chính; Hệ thống an toàn; Lò phản ứng WWER1000 . 